УДК 821.113.6.09(092)

DOI:

Уляна Куцик, аспірантка Дрогобицького державного педагогічного університету імені Івана Франка

\title{
ОБРАЗ ДЕТЕКТИВА У ТРИЛОГЇ̈ СТІГА ЛАРССОНА “МІЛЕНІУМ”: ПСИХОЛОГІЧНИЙ АСПЕКТ
}

У статті розглянуто образи головних персонажів трилогії Стіга Ларссона “Міленіум” Лісбет Саландер та Мікаеля Блумквіста. Зроблено спробу розкрити їхні характери головно через ставлення до них інших персонажів і навпаки. Проаналізовано їхні особистісні якості иляхом аналізу зовнішності героїв, способу життя та особливостей професійної діяльності. 3'ясовано, щуо це особистості непересічні, нетипові, подекуди дивакуваті, які виробили власне ставлення до моралі, до суспільства, загалом до життя.

Ключові слова: детектив; детективний жанр; класичний детектив; детективний роман; психологічний роман; образ детектива.

Jim. 11.

Ulyana Kutsyk, Postgraduate Student of Ivan Franko Drohobych State Pedagogical University

\section{IMAGES OF DETECTIVES IN STIG LARSSON'S TRILOGY “MILLENNIUM”: PSYCHOLOGICALASPECT}

The article analyses the main research and publications concerning detective genre, including classic detective as an independent genre of crime literature, the definition of typological features of women's detective novel, genre-style and gender aspects of American detective, English-speaking detective story in terms of its speechstylistic implementation and communicative-pragmatic tasks of transmitting meaning, etc.

The article tries to clear up unusual images of detectives Michael Blumquist and Lisbeth Salander in "Millennium" trilogy by the Swedish writer Stig Larsson, to find out what exactly distinguishes them from other famous literary detectives.

It is stated that in modern detective novels the very image of a detective is being changed: this is no longer an "ideal" person with only black and white, virtue and vice outlook, but a person that has formed his/ her own attitude to morals and society, usually this is a lonely person who is used to relying himself.

It was found out that a detective novel is combined with a psychological novel, borrows its style, structure.

Stig Larsson managed to create characters that are radically different from the usual characters in detective novels. The deviation from the genre of classic detective is that Michael Blumquist plays the role of chief investigator, and Lisbeth Salander is his assistant, but it is Lisbeth who becomes the main character of the trilogy.

The article shows that Lisbeth Salander in the trilogy was brought up as a freak both because of the peculiarities of her appearance and unusual psychological abilities: phenomenal memory, excessive isolation, inaccessibility.

The character traits of Michael Blumquist, who combined absolute simplicity with the oracle's insight, carelessness and ease with absolute seriousness and manic stubbornness, are analyzed.

It turned out that these individuals are extraordinary, atypical, sometimes eccentric, who have developed their own attitude to morality, society, and life in general.

Keywords: detective; detective genre; classic detective; detective novel; psychological novel; an image of a detective.

П остановка проблеми. Відомий у всьому світі шведський письменник і журналіст Стіг Ларссон прожив недовге життя - лише 50 років. Детективна трилогія романів-бестселерів "Міленіум” була опублікована вже після його смерті. Романи “Чоловіки, що ненавидять жінок”, “Дівчина, що гралася з вогнем" та "Повітряний замок, що вибухнув” перекладені майже всіма мовами світу, видані мільйонними тиражами.

У чому ж полягає феномен Ларссона? Чому детективи, які зазвичай читають задля розваги, як “легке чтиво”, використовують як

(C) У. Куцик, 2021 антидепресанти, стали настільки популярними серед найширшої читацької авдиторії? Читачам потрібна правда про світ - сьогоднішній і минулий, читачам потрібні моделі сприйняття цього світу. Письменники, такі геніальні, як Стіг Ларссон зокрема, допомагають їм вилучити правду про світ, збагнути їі, власну суб'єктивну думку заснувати на об'єктивних реаліях. До Ларссона мало кому було відомо, що стара добра Швеція, від епохи вікінгів, династії Вазів, які відкрили для країни нову еру, сучасна Швеція, яка асоціюється 3 “фікою”, з солодощами, плануванням усього на світі, зведеною в абсолют любов’ю до чистоти, 
затишку в оселях, - ця Швеція може бути зовсім іншою. Виявляється, тут не до кінця знищені нацистські традиції, тут насильницькою смертю можуть померти політики найвищого рангу, тут жінки піддаються насильству, і не лише жінки.

Аналіз основних досліджень і публікацій. Особливості детективного жанру були предметом аналізу багатьох учених. Так, метою дисертації Т. Гуляк стало визначення типологічних ознак жіночого детективного роману в прозі Дороті Сейерс та Ірен Роздобудько в контексті розвитку детективного жанру в британському й українському письменстві [2]. Жанрово-стильові й гендерні аспекти американського “крутого” детективу в творчості Сью Графтон, Сари Парецькі та Марсії Мюллер дослідила А. Титюк [7]. Наукові зацікавлення Л. Цапенко пов’язані $з$ питанням англомовної детективної розповіді в аспекті їі мовленнєво-стилістичної реалізації та комунікативно-прагматичних завдань передавання смислу [8;9]. Н. Кириленко присвятила монографію класичному детективу як самостійному жанру кримінальної літератури [3]. А. Гвоздєва проаналізувала лінгвокультурний образ детектив на прикладі двох яскравих персонажів - Шерлока Холмса та Еркюля Пуаро [1].

Трилогія Стіга Ларссона "Міленіум" в літературному світі викликала неабиякий ажіотаж, однак належного літературознавчого аналізу не отримала. Вітчизняних наукових досліджень, присвячених образу детектива у скандинавській літературі, немає. Науковим зацікавленням I. Шпака став детективний роман Ю Несбе Харрі Холе [11].

Метою нашої розвідки $\epsilon$ спроба висвітлити неординарні образи детективів у трилогії шведського письменника Стіга Ларссона "Міленіум" Лісбет Саландер та Мікаеля Блумквіста, з'ясувати, що саме вирізняє їх серед інших відомих в літературі детективів.

Виклад основного матеріалу. Класичний детектив як літературний жанр є доволі клішованим. Автор створює “досить стереотипного персонажа - приватного детектива, стандартний спосіб його життя, вчинків, ставлення до навколишнього. Зокрема й до поліції. За незначними винятками - негативне. Як правило, поліція не здатна розкрити злочин і своїми діями тільки заважає героєві” [10, 255]. Лише приватний детектив здатен розкрити злочин, хоча він допомагає поліції.

У сучасних детективних романах змінюється сам образ детектива. Це вже не “ідеальна" людина, для якої існує лише біле і чорне, добро і зло. Це людина, що виробила власне ставлення до моралі, до суспільства, зазвичай людина самотня, яка звикла розраховувати лише на себе.

Романи трилогії “Міленіум” об’єднує класична детективна історія: детектив та його помічник розслідують заплутані справи. Роль нишпорки та його помічниці виконують аматори: Мікаель Блумквіст - журналіст, а Лісбет Саландер хакер.

Стіг Ларссон в одному з інтерв'ю сказав, що він намагався створити героїв, які радикально різняться від звичайних персонажів у детективних романах. Чи письменник навмисно намалював їх неадекватними жанру? Відхилення від жанру класичного детектива полягає вже у тому, що Мікаель Блумквіст виконує роль головного слідчого, а Лісбет Саландер - його помічниці, як Шерлок Холмс і доктор Ватсон, як Ніро Фульф та Арчі Гудвін. Однак саме Лісбет стає головною героїнею трилогії.

Автор знайомить читача 3 внутрішнім світом своїх головних персонажів. Детективний роман поєднується з психологічним романом, запозичує його стиль, структуру.

Детектив-слідчий в очах навколишніх зазвичай видається неординарною особистістю, людиною, що має винятково якості, неабиякі таланти. У класичному детективі особливою характеристикою нишпорки $є$ його дивакуватість. У трилогії “Міленіум” Мікаель і Лісбет ніби міняються місцями.

“Дівчина 3 татуюванням дракона" - так звучить у перекладі з англійської назва першої книги трилогії (“The Girl with the Dragon Tattoo"), хоча український переклад найбільш точний зі шведської - “Чоловіки, що ненавидять жінок" ("Män som hatar kvinno").

Лісбет Саландер часто сприймається навколишніми дивачкою через особливості зовнішності, що характеризується підкресленою незвичністю та яскравою індивідуальністю. У першій книзі читач бачить їі насамперед очима Мікаеля Блумквіста: “У неї були численні татуювання, на обличчі був пірсинг” [4, 412].

У другому романі “Дівчина, що гралася 3 вогнем” автор-оповідач не раз описує зовнішність Лісбет, зміни в ній: “Маючи зріст сто п’ятдесят сантиметрів, вона, як і раніше, важила близько сорока кілограмів, і з цим, на жаль, нічого не можна було подіяти. Так само як 3 тонкими ляльковими кінцівками і вузькими стегнами, які не заслуговували на особливу увагу" [5, 22].

Чому взагалі люди роблять татуювання, особливо молоді дівчата? На думку психологів, це один зі способів підкріпити власну ідентичність, ствердити незалежність. Лісбет, як дівчина неординарна у своїй зовнішності, 
поведінці, способі мислення, йде ще далі: робить пластичну операцію зі збільшення грудей. “Ретельно продумана операція не порушила пропорцій фігури, проте викликала разючі зміни як у зовнішності Лісбет, так і в їі внутрішньому самовідчутті" [5, 23]. Трансформації їі тіла пов'язані насамперед 3 малюнками на шкірі: “Перебуваючи в генуезькій клініці, вона видалила одне із своїх дев'яти татуювань двосантиметрову осу, що прикрашала іiі шию $з$ правого боку. Лісбет любила всі свої татуювання, особливо великого дракона, який займав простір від плеча до сідниці, але оси вирішила все-таки позбутися: та була на видному місці і могла стати чудовою особливою прикметою" [5, 23]. Перемагають раціо, логіка, інстинкт самозбереження. Ïї неординарність і виявляється у незвичному поєднанні дорослої, досвідченої, розумної, талановитої людини та підлітка зовні: “Вона була незвичайна дівчина - цілком доросла по суті, але цілковитий підліток з вигляду" [5, 46].

Лісбет - неординарна особистість, надзвичайно обдарована дівчина. Вона наділена феноменальною пам'яттю. “Я був би радий мати наполовину таку гарну пам'ять, як у тебе”, - із захопленням говорить ӥй Мікаель [4, 508].

Феноменальною є здібність Лісбет, “всього лише перегортаючи матеріали розслідування”, логічно вибудовувати ланцюжок подій i вихоплювати 3 кожного епізоду деталі, “що викликали найбільші сумніви і не узгоджувались між собою" [4, 469]. Саме цю здатність їі натури поступово відкриває Мікаель.

Лісбет сподобалася Мікаелю з першої хвилини, 3 першої миті. 3 одного боку - це дівчина зі своєрідним стилем поведінки, спілкування, 3 довгими паузами посеред розмови, що свідчить про iï неординарність, закритість. “Адже ти найзамкнутіша і найнеприступніша особа з усіх, кого я знаю!" - так характеризує Лісбет їі подружа-лесбійка Міммі $[5,161]$. Вона називає Лісбет “чинником ентропії і хаосу” $[5,161]$.

Ларссон виводить у другому романі трилогії антипода Лісбет - iї сестру-двійника Каміллу. “Про сестру Лісбет згадувати не любила. Ї̈ разюча відмінність між собою самій Лісбет завжди здавалася якоюсь іронією долі. Вони народилися двійнятками, 3 різницею всього двадцять хвилин. Лісбет була старша. Камілла була красуня. Вони були зовсім не схожі одна на одну, і заледве вірилося, що вони вийшли з однієї матки. Коли б не якийсь невідомий збій в генетичному коді, Лісбет могла б стати такою ж писаною красунею, як і її сестра. І напевно, такою ж дурепою” $[5,123]$.
Вчинки Лісбет іноді не піддаються логіці. Надмірна замкнутість не заважає їй взяти на себе ініціативу розпочати інтимні стосунки з Мікаелем. Тендітна дівчина, підліток зовні, несподівано завдає потужного й рішучого удару опікуну адвокату Б'юрману. Вона спроможна захистити себе самотужки, оскільки шведське суспільство 3 його авторитарними традиціями не змогло зробити цього. Дівчина мстить всім чоловікам, які її образили. Ще у дванадцятирічному віці вона облила бензином і підпалила свого батька, тирана й гвалтівника. Опікунові-гвалтівнику Б’юрману Лісбет робить принизливі татуювання.

Можна стверджувати, що в образі цієї дівчини простежується своєрідна помста письменника за всіх жінок, що були піддані насильству.

Головним чоловічим персонажем трилогії "Міленіум" Стіга Ларссона є Мікаель Блумквіст - журналіст, який веде розслідування. Актуалізується думка, що саме волелюбна преса залишається останнім прихистком ідеалістів в часи переходу шведської нації в нове тисячоліття. Нагадаємо, що й сам Стіг Ларссон був журналістом i тонкощі та можливості журналістської професії були йому знайомі.

Читач бачить Мікаеля насамперед у стосунках 3 Лісбет Саландер. Коли дівчина намагається його спровокувати, читаючи документи в його комп'ютері у нього на очах, “він не оскаженів і не перевернув усе догори дном, а замість цього найняв її на роботу” $[4,475]$. "Він з нею працював,

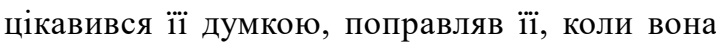
помилялася, визнавав іiї правоту, коли вона йому вичитувала. Чорт забирай, він ставився до неї як до людини" $[4,476]$.

У Мікаеля було багато жінок, але неабиякої ваги він надавав лише стосункам з Ерікою Бергер. Цей зв'язок тривав близько двадцяти років. Незрозумілі для навколишніх, для самої Еріки, яка була заміжньою, для Мікаеля, що понад усе цінував свободу у відносинах $з$ жінками, ці стосунки були як наркотична залежність. "Сама Еріка Бергер була дуже рада мати такого друга i надійного товариша, як Мікаель. У чомусь він був абсолютним простаком, зате в інших випадках проявляв проникливість оракула (...) Маючи дуже мінливий характер, він справляв враження людини, в якій уживаються кілька особистостей. У роботі він часом проявляв маніакальну впертість: узявшись до якої-небудь справи, він працював над нею, доки досягав досконалості, зібравши в один вузол усі розрізнені нитки" [4, 173-174]. Таким постає Мікаель очима начальниці, коханки, друга Еріки Бергер в першому романі трилогії.

Ïї думка про Мікаеля як колегу також влучна 
й лаконічна: "Гіршого головного редактора ви просто не знайдете. Він ідеальний відповідальний редактор, класно проводить розслідування і переробляє для публікації статті. Але на посаді головного редактора він загальмовує всю роботу. До того ж Мікаель має схильність періодично поринати у власні історії і пропадати на цілі тижні. Його стихія - пожежа, та він геть непридатний для рутинної роботи" $[6,59]$.

В очах оточення Мікаель Блумквіст часто виглядав безтурботним і невимушеним, однак обличчя його залишалося серйозним. Здатність контролювати свої емоції допомагала йому як у веденні журналістських розслідувань, так і в різних кризових ситуаціях.

Висновки. Образи детективів у трилогії "Міленіум" розглянуто нами шляхом аналізу зовнішності героїв, способу життя та особливостей професійної діяльності, а також через ставлення до них інших персонажів і навпаки. 3'ясовано, що детектив-хакер Лісбет Саландер поєднує в собі риси неординарних, подекуди психопатичних особистостей: ігнорування суспільних норм, асоціальний стиль життя й поведінки, надмірна замкнутість, навмисна відчуженість від суспільства тощо. Водночас це дівчина з високими інтелектуальними здібностями, нестандартним типом мислення. Вона здатна працювати на відмінно, логічно мислити, бачити у кримінальній справі те, що не лежить на поверхні, що не помічають інші.

Журналіст-детектив Мікаель Блумквіст також неординарна особистість, людина смілива, розумна, наполеглива, вперта, іноді непередбачувана.

Головні персонажі трилогії Стіга Ларссона “Міленіум" привабливі саме завдяки своїй нетиповості, дивакуватості, неординарності.

\section{ЛІТЕРАТУРА}

1. Гвоздева А.В. Лингвокультурный образ детектив : автореферат дис. ... канд. філолог. наук : 10.02.19 . Челябинск, 2009. $23 \mathrm{c}$.

2. Гуляк Т.М. Модифікації жіночого детективного роману у творчості Дороті Сейерс та Ірен Роздобудько : автореферат дис. ... канд. філолог. наук : 10.01.05; ДВНЗ "Прикарпатський національний університет імені Василя Стефаника”. Івано-Франківськ, 2019. 18 с.

3. Кириленко Н. Классический детектив как жанр криминальной литературы (инвариант и генезис) Екатеринбург: Издательство “Кабинетный учёный”, $2020.246 \mathrm{c}$.

4. Ларссон С. Чоловіки, що ненавидять жінок : міленіум : скандинавський гостросюжетний роман. переклад В.М. Верховня. Харків : Фоліо 2010. 702 с.

5. Ларссон С. Дівчина, що гралася з вогнем : міленіум : скандинавський гостросюжетний роман. переклад В.М. Верховня. Харків : Фоліо 2011. 829 с.
6. Ларссон С. Повітряний замок, що вибухнув : міленіум : скандинавський гостросюжетний роман. переклад В.М. Верховня. Харків : Фоліо 2011. 894 с.

7. Титюк А.К. Жанр “жіночий детектив” в оцінках літературної критики. Наукові записки Харківського національного педагогічного університету імені Г.С. Сковороди. Серія: Літературознавство. 2013. Вип. 2(2). С. 122-128.

8. Цапенко Л.В. Детективна розповідь: до проблеми визначення. Наукові записки Національного університету “Острозька академія". Серія “Філологічна" : збірник наукових праць / укладачі : І.В. Ковальчук, Л.М. Коцюк, С.В. Новоселецька. Острог: Видавництво Національного університету “Острозька академія", 2015. Вип. 58. С. 128-130.

9. Цапенко Л.В. Типологічна диференціація різновидів англомовної детективної розповіді. Науковий вісник Дрогобицького державного педагогічного університету імені Івана Франка. Серія: “Філологічні науки” (мовознавство) : збірник наукових праць. Том 2. № 5. Дрогобич, 2016. С. 153-156.

10. Честертон Г.К. Как сделать детектив. Москва: Радуга, 1990. С. 255-256.

11. Шпак I.B. Скандинавский NOIR HERO детективного романа. URL: http://journals.hnpu.edu.ua/ index.php/literature/article/view/1168

\section{REFERENCES}

1. Gvozdeva, A.V. (2009). Lingvokulturnyj obraz detektiv [Linguocultural image of a detective]. Extended abstract of candidate's thesis. Chelyabinssk, 23 p. [in Russian].

2. Gulyak, T.M. (2019). Modyfikatsii zhinochoho detektyvnoho romanu u tvorchosti Doroti Seiers ta Iren Rozdobudko [Modifications of the female detective novel in the works of Dorothy Sayers and Irene Rozdobudko]. Extended abstract of candidate's thesis. Ivano-Frankivsk, 18 p. [in Ukrainian].

3. Kirilenko, N. (2020). Klassicheskij detektiv kak zhanr kriminalnoj literatury (invariant i genezis) [Classic detective story as a genre of criminal literature (invariant and genesis)]. Yekaterinburg, 246 p. [in Russian].

4. Larsson, S. (2010). Choloviky, shcho nenavydiat zhinok: milenium : skandynavskyi hostrosiuzhetnyi roman [Men who hate women: the millennium: a Scandinavian action novel]. Kharkiv, 702 p. [in Ukrainian].

5. Larsson, S. (2011). Divchyna, shcho hralasia z vohnem : milenium : skandynavskyi hostrosiuzhetnyi roman [The girl who played with fire: the millennium: a Scandinavian action novel]. Kharkiv, 829 p. [in Ukrainian].

6. Larsson, S. (2011). Povitrianyi zamok, shcho vybukhnuv : milenium : skandynavskyi hostrosiuzhetnyi roman [Exploded air castle: the millennium: a Scandinavian action novel]. Kharkiv, 894 p. [in Ukrainian].

7. Tityuk, A.K. (2013). Zhanr "zhinochyi detektyv" v otsinkakh literaturnoi krytyky [The genre of "female detective" in the assessments of literary criticism]. Scientific notes of H.S. Skovoroda Kharkiv National Pedagogical University. Kharkiv, Vol. 2 (2), pp. 122-128. [in Ukrainian].

8. Capenko, L.V. (2015). Detektyvna rozpovid: do 


\section{ПЕДАГОГІЧНІ УМОВИ ФОРМУВАННЯ ДИРИГЕНТСЬКО-ХОРОВОӤ КУЛЬТУРИ У ПРОЦЕСІПІДГОТОВКИ СТУДЕНТІВ ПЕДАГОГІЧНИХ ВУЗІВ}

problemy vyznachennia [Detective story: to the problem of definition]. Scientific notes of the National University Ostroh Academy. Series Philological: a collection of scientific works / compilers: I.V. Kovalchuk, L.M. Kotsyuk, S.V. Novoseletsk. Ostroh, Vol. 58, pp.128-130. [in Ukrainian].

9. Capenko, L.V. (2016). Typolohichna dyferentsiatsiia riznovydiv anhlomovnoi detektyvnoi rozpovidi [Typological differentiation of varieties of Englishlanguage detective story]. Scientific Bulletin of
Drohobych State Pedagogical University named after Ivan Franko. Series: "Philological Sciences"(linguistics): a collection of scientific papers. Drogobych, Volume 2 , No. 5. pp. 153-156. [in Ukrainian]

10. Chesterton, G.K. (1990). Kak sdelat detektiv [How to make a detective]. Moscow, pp. 255-256. [in Russian].

11. Shpak, I.V. Skandinavskij NOIR HERO detektivnogo romana [Scandinavian NOIR HERO detective novel] Available at: http://journals.hnpu.edu.ua/index.php/ literature/article/view/1168 [in Russian].

Стаття надійшла до редакції 06.01.2021

УДК 378.147.7.071.2

DOI:

Юрій Сіка, аспірант кафедри мистецьких дисциилін і методик навчання ДВНЗ “Переяслав-Хмельницький державний педагогічний університет імені Григорія Сковороди”

\section{ПЕДАГОГІЧНІ УМОВИ ФОРМУВАННЯ ДИРИГЕНТСЬКО-ХОРОВОЇ КУЛЬТУРИ У ПРОЦЕСІ ПІДГОТОВКИ СТУДЕНТІВ ПЕДАГОГІЧНИХ ВУЗІВ}

У статті розглянуто педагогічні умови, щзо визначають, специфіку $і$ організацію педагогічного освітнього прочесу диригентсько-хорової культури студентів педагогічних ЗВО. Уточнено поняття “педагогічні умови”. Проаналізовано сучасні праці щуодо визначення педагогічних умов майбутніх учителів музичного мистецтва. Наведено характеристики визначених умов навчального прочесу диригентсько-хорової культури майбутніх фахівців, які підвищують рівень навчального процесу з формування диригентсько-хоровоі культури у проиесі підготовки студентів педагогічних 3 ВО.

Ключові слова: педагогічні умови; диригентсько-хорова культура; музичне мистецтво; майбутні фахівиі; педагогічні вузи.

Jim. 6.

Yuriy Sika, Postgraduate Student of the Art Disciplines and Teaching Methods Department, State Institution of Higher Education "Pereyaslav-Khmelnytsky Hryhoriy Skovoroda State Pedagogical University"

\section{PEDAGOGICAL CONDITIONS OF FORMATION OF CONDUCTOR AND CHOIR CULTURE IN THE PROCESS OF TRAINING STUDENTS OF PEDAGOGICAL HIGHER EDUCATION INSTITUTIONS}

The article considers the pedagogical conditions that determine the specifics and organization of the pedagogical educational process of conducting and choral culture of students of pedagogical universities. Analyzing the scientific works of researchers clarified the meaning of "pedagogical conditions", which is the circumstances associated with the organization of the educational process in higher education, aimed at the formation of professional knowledge, skills and abilities, the development of their worldview culture.

In this regard, a set of pedagogical conditions that increase the level of formation of conducting and choral culture in the process of training students of pedagogical universities:

1) ensuring awareness of the importance of forming conducting and choral culture and readiness to implement it in the future profession of students of pedagogical universities, characterizing a positive attitude to profession, which depends on the formation of motives, the internal need for the development of musical competencies; 2) actualization of interdisciplinary integration and its program-methodical support in the formation of conducting and choral culture in the process of training students of pedagogical universities, which provides for the content of certain disciplines and creating educational process of educational potential through the use of pedagogical principles, organizational forms and methods; 3) purposeful application in the educational process of a set of modern technological and information and communication tools, which characterizes the leading role of information and communication, media tools of modern conducting and choral training; 4) ensuring the students' awareness of the need for reflective and evaluative activities in the process of preparation for the formation of conducting and choral culture, which provides the ability to provide self-control and evaluation of the formation of conducting and choral culture of students of pedagogical universities.

Thus, the consistent implementation of certain pedagogical conditions is designed to ensure the optimization 